\title{
Molecular analysis of an extended Palestinian family from Israel with monilethrix
}

\author{
William S. Oetting, PhD', James P. Fryer, BS , Zachery Wyman ${ }^{l}$, Atalia Shtorch, PhD', Mario Cordoba, $M D^{3}$, \\ Aneta Lazarov, $M D^{4}$, and Orit Reish, $M D^{2.5}$
}

We describe the molecular analysis of a large three generation Palestinian family segregating for monilethrix. Previous reports have shown that mutations in type-ll hair cortex keratin genes, $\mathrm{hHb1}$ and $\mathrm{hHb6}$, are associated with monilethrix. Genetic linkage analysis performed on this family using markers flanking the $\mathrm{hHb} 6$ gene exhibited strong evidence for linkage. Sequence analysis revealed a nucleotide substitution of $\mathrm{G} \rightarrow \mathrm{T}$ at nucleotide 1230 resulting in a glutamic acid to aspartic acid amino acid substitution at codon 410 , identical to that reported in a French family. The family in our study provides further evidence that mutations of the $\mathrm{hHb} 6$ gene are responsible for monilethrix.

\section{INTRODUCTION}

Monilethrix, a rare autosomal dominant disorder with high penetrance and variable expression, is characterized by an abnormal cuticle of the hair shaft resulting in irregularly beaded nodes or moniliform hair that shows a high propensity to fracturing, sometimes resulting in alopecia. ${ }^{1,2}$ In several families, monilethrix has been mapped to chromosome $12 \mathrm{q} 13$, which contains the type-II keratin gene cluster. ${ }^{3-5}$ Most families segregating for monilethrix have been European, but an Indian ${ }^{6}$ and an Arabian $^{7}$ family have been reported.

Missense mutations in two type-II hair cortex keratin genes, hHbl and hHb6, have been found in individuals with monilethrix. ${ }^{8,9}$ In both genes, the homologous codon, a highly conserved glutamic acid in the helix termination motif, has been the location of an amino acid substitution which is thought to be the cause of their monilethrix. We have identified a large, three generation Palestinian family from Israel that segregates for monilethrix. Molecular analysis revealed a mutation in the hHb6 gene and provides further evidence that mutations of the hHb6 gene are responsible for monilethrix.

From the 'Department of Medicine, University of Minnesota, Minneapolis, MN the 'Department of Human Genetics, Meir Hospital, Kefar Saba, Israel; the Department of Pathology, Meir Hospital, Kefar Saba, Israel; the 'Dermatology' Clinic, Mcir Hospital, Kefar Saba, Israel; and the ${ }^{5}$ Department of Pediatrics, Tel Aviv University, Tel Aviv, Israel.

Address correspondence to: William S. Oetting, PhD), Departnent of Medicinc, Box 485 Mayo, 420 Delaware St. SE, University of Minnesota, Minncapolis, MN 55455. E-mail:bill@lenti.med.umn.edu

(c) 1999 Genetics in Medicine. All rights reserved. 1098-3600\$3.00

\section{MATERIALS AND METHODS}

\section{Clinical sample}

An extended Palestinian family from Israel was identified segregating for autosomal dominant monilethrix (Fig. 1). All members lived in the same village having a similar socioeconomic level. Diagnosis was established by dermatologic examination and light microscopic investigations of hairs from each individual. The family contains 57 members with 23 clinically affected individuals. Hallmarks of the disease (beaded, fragile hair, and dystrophic alopecia) were present in all clinically affected patients. However, remarkable differences in the phenotype were noted between individuals in the same nuclear family. Follicular keratosis was exclusively noted over the scalp and neck of severely affected individuals (II-1, III-3, III-5, III-17, II-13, III-23). No patient had fragility or splitting of nails. Whole blood was obtained from 51 family members and DNA from lymphocytes was isolated according to Miller et al. ${ }^{10}$

\section{Linkage analysis}

STRP markers D12S368 and D12S96 were used for linkage analysis. Amplification of markers was done using a three primer PCR reaction as previously described. " Marker patterns were visualized using a LI-COR Model 4200 automated infrared sequencer and allele sizes were determined using Gene ImagIR software (LI-COR, Inc., Lincoln, NE). Linkage analysis was performed using analysis programs from the $C$ version of the LINKAGE package FASTLINK ${ }^{12,13}$ and the utility programs Makeped, LCP, LRP, and UNKNOWN from LINKAGE 5.1. ${ }^{14}$ 




Fig. 2 (A) Mutational analysis of the hHb6 gene. Individual II-7 had monilethrix and her daughter, individual III-10, had a normal phenotype. Individual III-7 was heterozygous for a $G$ and $T$ at nucleotide 1230 . (B) Sequencing results. A nucleotide substitution at 1230 of $G \rightarrow T$ results in an amino acid substitution of glutamic acid to aspartic acid. The highly conserved motif, TYRKLLEGE, at the end of the rod domain is shown as the first 9 amino acids in the sequence.

\section{Sequence analysis}

Primers reported by Winter et al. ${ }^{8}$ were used for the sequencing of the hHb6 gene. Regions to be sequenced were first amplified using the PCR reaction. ${ }^{15}$ The forward primer for each amplification primer pair contained an M13 tail, and a primer labeled with a fluorescent dye was used as the sequencing primer. Sequencing was done using a cycle sequencing kit (Promega, Madison, WI) and the sequencing ladder was produced and visualized using an infrared fluorescent automated DNA sequencer (LI-COR, Inc., Lincoln, NE).

\section{RESULTS AND DISCUSSION}

The monilethrix phenotype segregated in an autosomal dominant mode of inheritance. Follicular keratosis is one of the features detected in some of the patients with monilethrix. In the kindred, follicular keratosis was exclusively noted over the scalp and neck of 6 of the 25 affected individuals. Except for one case, the keratosis phenotype clustered in nuclear families. There were no known differences in the environment, indicating that other modifying genes may be responsible for the differences in the phenotype. To determine the cause of monilethrix in this family, we first analyzed hHb6 as a candidate locus. Genetic linkage analysis was performed using two markers on chromosome 12 q13 flanking the hHb6 gene (D12S368 and D12S96). ${ }^{3}$ The consanguineous matings in this pedigree were analyzed as nonconsanguineous matings, which should result in a more conservative analysis. Both markers gave strong evidence for linkage. The marker D12S368 gave a lod score of 3.91 and D12S96 gave a lod score of 5.07, both for $\Theta=0.0$.

Based on the linkage results, we sequenced exon 7 of the hHb6 gene, where a "hot spot" for mutations in this gene had been previously reported. ${ }^{8,9} \mathrm{~A}$ base substitution of $\mathrm{G} \rightarrow \mathrm{T}$ at nucleotide 1230 (Fig. 2A), resulting in a glutamic acid to aspartic acid amino acid substitution at codon 410 (E410D), was identified (Fig. 2B). Sequencing analysis showed that affected individuals I-1, II-1, II-7, II-13, and III-31 were all heterozygous for this base substitution. Unaffected individuals I-2, II3 , and III- 10 were found to have a normal DNA sequence at this codon. This base substitution is identical to the mutation reported by Winter et al. ${ }^{8}$ in a three generation French family segregating for monilethrix. This mutation may reflect an old mutation that is in both the Palestinian and French populations, or a mutational hot spot in a conserved critical region of the hHb6 gene. Linkage analysis of the French family was not performed, preventing comparison of haplotypes in these two pedigrees. No genotype/phenotype correlations can be concluded because the same mutation results in a variable phenotype. A different mutation at the same codon (E410K), due to a base substitution of $G \rightarrow A$ at nucleotide 1228 resulting in a glutamic acid to lysine amino acid substitution, has also been reported in a British family ${ }^{8}$ and in a German family. ${ }^{9}$ A mutation in the $\mathrm{hHbl}$ gene, also a type-II hair keratin, affecting the homologous codon E403K was also reported. ${ }^{9}$

This glutamic acid is part of a highly conserved 9 amino acid motif of the helix termination peptide (TYRKLLEGE), which is at the C-terminal end of the rod domain found in all types of intermediate filament proteins that include type-II hair keratins and other keratins. ${ }^{16}$ Heterodimers containing mutations in this motif were shown to alter intermediate filament formation. Disease-causing missense mutations involving a glutamic acid in an equivalent position at the end of this motif have also been reported in families with ichthyosis bullosa of Siemens in the keratin $2 \mathrm{e}$ gene, ${ }^{17,18}$ epidermolysis bullosa simplex in the keratin 5 gene, ${ }^{19}$ and Meesmann's corneal dystrophy in the keratin 3 gene ${ }^{20}$ showing the importance of this motif to proper protein function.

\section{Acknowledgments}

The authors would like to thank the families for their willingness to participate in this study.

\section{References}

1. Mckee GM, Rosen J. Monilethrix: A clinical and histological study with a report of six cases and a review of the literature. J Cutan Dis Syph 1961;34:444-462.

2. Carreras D. Monilethrix: A review and case report. Pediatr Dent 1996;18:331-333.

3. Healy E, Holmes SC, Belgaid CE, Stephenson AM, McLean WHI, Rees JL, Munro CS. A gene for monilethrix is closely linked to the type II keratin gene cluster at 12q13. Hum Mol Genet 1995;4:2399-2402.

4. Stevens HP, Kelsell DP, Bryant SP, Bishop DT, Dawber RPR, Spurr NK, Leigh IM. Linkage of monilethrix to the trichocyte and epithelial keratin gene cluster on 12q11-q13. J Invest Dermatol 1996;106:795-797.

5. Birch-Machin MA, Healy E, Turner R, Haldane F, Belgain CE, Darlington $S$, Stephenson AM, Munro C, Messenger AG, Rees JL. Mapping of monilethrix to the type II keratin gene cluster at chromosome $12 q 13$ in 
three new families, including one with variable expressivity. Br J Dermatol 1997;137:339-343.

6. Bajaj AK, Swarup V, Gupta SC, Shukla SR, Pande RC, Gupta OP. Monilethrix. Dermatologica 1978;156:292-295.

7. Schaap T, Even-Paz Z, Hodes ME, Cohen MM, Hacham-Zadeh S. The genetic analysis of monilethrix in a large inbred kindred. Am J Med Genet 1982;11:469-474.

8. Winter H, Rogers MA, Langbein L, Stevens HP, Leigh IM, Labrèze C, Roul $\mathrm{S}$, Taieb A, Krieg T, Schweizer J. Mutations in the hair cortex keratin hHb6 cause the inherited hair disease monilethrix. Nat Genet 1997;16:372-374.

9. Winter H, Rogers MA, Gebhardt M, Wollina U, Boxall L, Chitayat D, Babul-Hiyi R, Stevens HP, Zlotogorski A, Schweizer J. A new mutation in the type II hair cortex keratin hHbl involved in the inherited hair disorder monilethrix. Hum Genet 1997;101:165-169.

10. Miller SA, Dykes DD, Polesky HF. A simple salting out procedure for extracting DNA from human nucleated cells. Nucleic Acids Res 1988;16:1215

11. Oetting WS, Lee H, Flanders D, Wiesner G, Sellers T, King RA. Linkage analysis with multiplexed short tandem repeat polymorphisms using infrared fluorescence and M13 tailed primers. Genomics 1995;30:450-458.

12. Cottingham RW Jr, Idury RM, Schäffer AA. Faster sequential genetic linkage computations. Am J Hum Genet 1993;53:252-263.

13. Schäffer AA, Gupta SK, Shriram K, Cottingham Ir RW. Avoiding recom- putation in genetic linkage analysis. Hum Hered 1994:44:225-237.

14. Lathrop GM, Lalouel JM. Easy calculations of LOD scores and genetic risks on small computers. Am J Hum Genet 1984;36:460-465.

15. Saiki R, Bugawan TL, Horn GT, Mullis KB, Erlich HA. Analysis of enzymatically amplified b-globin and HLA-DQa DNA with allele-specific oligonucleotide probes. Nature 1986;324:163-166.

16. Hatzfeld M, Weber K. Modulation of keratin intermediate filament assembly by single amino acid exchanges in the consensus sequence at the $\mathrm{C}$ terminal end of the rod domain. J Cell Sci 1991;99:351-362.

17. Kremer H, Zeeuwen P, McLean WH, Mariman ECM, Lane EB, van de Kerkhof PCM, Ropers HH, Steijlen PM. Ichthyosis bullosa of Siemens is caused by mutations in the keratin 2e gene. I Invest Derm 1994,103:286-289.

18. Jones OM, Watts C, Mills C, Sharpe G, Marks R, Bowden PE. A new keratin 2e mutation in ichthyosis bullosa of Siemens. Jnvest Derm 1997;108:354-356.

19. Stephens K, Ehrlich P, Weaver M, Le R, Spencer A, Sybert VP. Primers for exon-specific amplification of the KRT5 gene: Identification of novel and recurrent mutations in epidermolysis bullosa simplex patients. I Invest Derm 1997; 108:349-353.

20. Irvine AD, Cordon LD, Swensson O, Swensson B, Moore JE, Frazer DG, Smith FJ, Knowlton RG, Christophers E, Rochels R, Uitto J, McLean WH. Mutations in cornea-specific keratin K3 or K12 genes cause Meeshann's corneal dystrophy. Nat Genet 1997;16:184-187. 